\title{
Perspectives on strategic internationalization: Developing capabilities for renewal
}

Monica Riviere, ISC Paris Business School) and Gabriele Suder (Melbourne Business School)

\section{ABSTRACT}

While strategic renewal has increasingly received interest from strategy scholars (BadenFuller \& Vorberda, 1997; Huff, Huff \& Thomas 1992; Crossan \& Berdrow, 2003; Agarwal \& Helfat, 2009; Capron \& Mitchell, 2009; Huang, 2009; Gulati \& Puranam, 2009), its gains from internationalization are less understood. We draw on both internationalization and strategy literature to investigate what is known about 'if' and 'how' firms renew their capabilities through internationalization. We anticipate that the scope of internationalization is positively associated with a firm's ability to create alternatives for renewal, thus allowing for the development of renewal capabilities. Yet we also draw attention to the factors that may represent limitations of the role of internationalization for strategic renewal. Internationalization strategies related to location, timing and venture mode decisions are antecedents to capability renewal strategies, uncovered as linear vs. non-linear renewal paths. Keywords: internationalization, renewal capabilities, capability development, dynamic capabilities

\section{Introduction}


In markets that are characterized by increasingly short product life cycles, the pressure to give timely responses to market demands leads organizations to redefine the conceptual boundaries of innovation. For internationalized organizations, the perpetual search for opportunities to sustain competitive advantages in the home and host markets has become instrumental to achieving what was formerly accomplished by a conventional steady quest for better products or services to serve the market.

Different contemporary theoretical perspectives consequently advance the need and notion of a different focus regarding the antecedents, forms, and consequences of firms' ability to maintain competitive advantages. The "process, content, and outcome of refreshment or replacement of attributes of an organization that have the potential to substantially affect its long-term prospects" (Agarwal \& Helfat, 2009: 282) is what the literature refers to as strategic renewal. Therefore, "the firm's ability to integrate, build and reconfigure internal and external competences to address rapidly changing environments" (Teece, Pisano \& Shuen 1997:516), shapes the dynamic capabilities of the firm there-in, and the internationalization of firms in a highly globalized business environment broadens the context there-of. In both cases, literature refers -directly or indirectly- to a process of renewal led by the firm's dynamic capabilities.

While the strategy literature rarely refers to it as such, 'Internationalization' has become critical to this discussion since there is recognition that the need to refresh capabilities and renew the business fuels cross-border expansion (Teece, 2014). Not only this, but vice - versa, scholarly study stipulates that the diversification of a firm's international reach and engagement fuels its capacity to capture and transpose ideas, and to explore and exploit innovation. Moreover, as a number of studies contend, the benefit of dynamic capabilities is contingent to the environment where they are deployed and that they are not exclusively relying on the existence of underlying organizational routines (Schilke, 2014). 
To date, the explicit link between internationalization and strategic renewal has not been clearly exposed. This is a conceptual gap that this paper fills by intersection of literature streams. The custody of dynamic capabilities relevant to internationalizing ${ }^{1}$ appears to be one crucial potentiality that can lead to the organization's renewal and survival: A firm that has these capabilities "can create and capture additional value by scaling them globally" (Pitelis $\&$ Teece, 2010). In addition, firms face the pressure of globalization even if they choose to operate in the home market exclusively; in the internationalized firm, competitive advantages are created and sustained when organizations transfer competences and forms across borders (Teece, 2014).

With this conceptual study, we thus investigate the role of internationalization for strategic renewal in the postulation that firms' efforts to align to the changing environment in the international context consequently evolve within an international process, in extension of Teece's seminal work (2014). Although the dynamic capability literature discusses the role of strategic decisions in the capability to cope with changing environments, it has not explicitly considered internationalization decisions or firms' international strategies despite the increasing amount of evidence suggesting the role of internationalization related to the sustainability of competitive advantages or innovation gains (Teece, 2014, Doz, Santos \& Williamson, 2001; Kafouros, Buckley, Sharp \& Wang, 2008; Meyer, Wright \& Pruthi; 2009; Bertrand \& Mol, 2012, Leiponen \& Helfat, 2010).

In addition, strategic renewal research falls short yet to discuss internationalization as a process involving the recognition, understanding, assimilation, and utilization of (potentially) valuable knowledge outside firms' home countries as instrumental to the longterm prospects of the firm. Strategic renewal literature, among means of renewal, enlists innovation through $\mathrm{R} \& \mathrm{D}$, acquisitions, product development, or market entry as significant

\footnotetext{
1 We understand internationalizing as firms in different stages of their internationalization process and of different sizes.
} 
factors. Dougherty (1992) already suggested that understanding "organizational renewal must be based on the practices that produce renewal-creating and exploiting the knowledge necessary to craft viable products" (p.90). On basis of contemporary literature, we now advance that internationalization is one of these practices, and we consequently query the potential of the different internationalization decision strategies in regards to their impact on the successful refreshment of organizations' attributes, i.e., strategic renewal. In doing so, we also extend the work of Kafouros et al. (2008) who establish that internationalization is a significant firm-level factor in improving performance through innovation. We propose that internationalization is part of the key firm-level factors with a potential to increase renewal capability and consequently, survival ${ }^{2}$.

Firms' renewal capability and the resulting strategy develop and vary in accordance to internationalization decisions. Internationalization decisions relate to a firm's strategies linked to the location and timing of its internationalization process, and the modes of venturing abroad, as extensively analyzed in traditional internationalization studies of International Business (IB) literature. In internationalization studies, decisions related to location, timing and the venture strategies are analyzed in relationship to performance, and sometimes within the study of the survival of the firm. However, these lenses have yet to take into account how distinct internationalization decisions allow firms to develop renewal capabilities. This aspect has not been thoroughly studied, neither in strategy nor in IB research, and is not clearly linked one to another despite the potential conceptual avenues this may open up. To fill this gap we start an academic discussion in which we examine how internationalization benefits the firm at different stages of its renewal process, that are distinguished into (a) the sensing phase, i.e., the stage when the firm recognizes and assesses the potential value of knowledge and capabilities outside the firm, and (b) the seizing and

\footnotetext{
2 Although we do not specifically consider or discuss survival itself, which is a discussion outside of the scope and goal of this study.
} 
applying (transforming) stage, when the firm assimilates external knowledge and capabilities and applies them to produce value and rents.

Following this logic, we develop propositions about the potential of internationalization to the firm's competitive sustainability, approaching both internationalization and renewal as processes that require resources and commitment (Huff et al., 1992). Those are neither unlimited nor unconditional, but both are part of a firm's strategy and shape it.

We link the relevant streams of literature from both, the strategic management and IB fields, which helps investigate the following questions:

(1) How does internationalization allow for the development of renewal capabilities for long-term survival?

(2) How do internationalization strategies - involving decisions related to location, internationalization timing and venture modes - impact a firm's renewal strategy? Is this 'applying' of dynamic capabilities rather a linear phenomenon, i.e., a series of related pathdependent innovations, or rather non-linear, i.e., undertaken outside the core activity?

The paper develops as following: First we review the concept of renewal from different strategy perspectives; then we discuss the potential role of internationalization to renewal and particularly how internationalization and internationalization strategies, as revealed in IB literature, reflect in renewal capability development and renewal strategy. We then build proposition around the effect of diverse internationalization decisions to the renewal of the firm and conclude by stipulating how this study and further empirical extensions of it - that analyze the propositions further- will contribute to strategy and IB literature.

\section{Perspectives on renewal}

\subsection{Renewal in strategy}


Huff et al. (1992) suggest that the concept of strategic renewal replaces an older strategic change "phrase" to emphasize that "strategic redirection is evolutionary... it grows out of (a) current situation and is accomplished over time" (p.55). The antecedents and outcomes of 'strategic renewal' are often overlapping with 'strategic change'. Agarwal \& Helfat (2009) refine scholarly understanding with a distinction between renewal and change, stating that "renewal is one type of change" (p.282): Indeed, while change can be accomplished through innovation but also extensions and deletions, none of latter will be engendering refreshment or replacement. Yet strategic renewal literature focuses particularly on purposeful rejuvenation of firms' attributes with the potential to reposition the firm in its competitive environment through goals, products, and policies. This repositioning encompasses the scope (domain) of the business, as well as its product-market level diversity (Barker \& Duhaime, 1997), in a constructive change context of renewal. It is worth noting that renewal also includes or may lead to change in an organization's "structure, administrative systems, and policies that define and coordinate work" (Agarwal \& Helfat, 2009:282).

In strategy literature, renewal is explored from different perspectives: as an outcome of an interacting organizational inertia and stress (Huff et.al., 1992), as a practice-centered model of product innovation (Dougherty, 1992), as a type of corporate entrepreneurship (Stopford \& Baden-Fuller, 1994), as an opportunity for organizational learning (Crossan \& Berdrow, 2003), and as a cyclical sense-making/ sense-giving process at the initiation stage of change (Gioia \& Chittipeddi, 1991). Convergent, though varied, perspectives on operationalization gather around several key notions that drive this change, and that may encompass tension (routines-change), process (evolution), reconfiguration (refreshment), and/or fit (firm-environment). Despite the implicit assumption that strategy plays a role in 
renewal, it is important to note that early literature views renewal as a primarily adaptive reflex to environmental shifts (including competition, technology, and market fragmentation), meaning that change - as a response to uncertainty - is managed ex-post-facto. Empirical studies, sharing this view, rely on financial ratios to determine performance deterioration or model out firm decline as "pathology in organizational decision-making and adaptation process" (Barker \& Duhaime, 1997).

Interestingly, however, the evolutionary firm-environment fit has been defined by the dynamic capabilities literature as a rational response to resource and capabilities alteration (Teece, et al., 1997; Eisenhardt \& Martin, 2000; O’Reilly \& Tushman, 2008), a due process that is persistent (Ambrosini, Bowman \& Collier 2009: 30) and targets both continuous reactive and also, proactive change (Teece, 2007). Here, where opportunities and information processing are given high importance, firms can exploit knowledge and capabilities outside their borders, and the environment can be, to some extent, endogenously determined (Teece, 2007; Vahlne \& Johanson, 2013).

This dilemma is ample evidence that a conceptual study emanating from both streams of literature may reveal new paths for theory building efforts in this field.

\subsection{Renewal from an evolutionary perspective}

The rationale that firms need to renew knowledge and capabilities in light of opportunities and environmental threats, actual or anticipated, is dominant in the dynamic capability literature. It is also in line with one of the two schools of organizational change that deems organizations to be relatively malleable and able to adapt to environmental changes (as opposed to the other school, which argues that organizations are rather inert and do not change). Strategic renewal is seen as both a continuum of and emergent from dynamic 
capabilities toward organizational change. Zahra \& George (2002: 188) explain that, “dynamic capabilities are geared toward effecting organizational change; they are essentially strategic in nature and, therefore, define the firm's path of evolution and development". In practice, renewal may be pursued through $\mathrm{R} \& \mathrm{D}$, the development of new products, or through acquisitions (Argawal \& Helfat, 2009). When such activities are pursued on a regular basis, under an opportunity sensing-seizing-applying logic, to maintain competitiveness, then they are the expressions of a firm's dynamic capabilities and are triggers for organizational change.

The regular nature of competence- renewing activities gives strategic renewal a process dimension, that is, renewal is not only a matter of content. Central in those studies that discuss renewal as a process, is the ongoing tension that accompanies change as incremental or discontinuous, for instance due to internal social contexts in capability sourcing selection decision (Capron \& Mitchel, 2009), formal and informal organizational structure (Gulati \& Puranam, 2009), micro-processes in the adaptation of new product development capabilities, or effects of shared cognition in post-acquisition integration (Agarwal \& Helfat, 2009). The literature suggests that one way of dealing with the tension between "state" and "change" is the institutionalization of continuous renewal (Agarwal \& Helfat, 2009). In the dynamic capabilities view, this is a higher order routine (process) for searching and learning. Indeed, Stopford \& Baden-Fuller (1994) conceptualized renewal as a process that is neither a single event nor a series of events, but rather encompasses "decision frames and heuristics that inform firm's investment choices over time" (Vahlne \& Johanson, 2013: 198).

\subsection{Linear vs. non-linear renewal}


Renewal from the evolutionary perspective is therefore a process that is continuous, purposively directed and positively institutionalized through routines to search and learn. Yet, renewal also has another dimension that directly reflects a firm's product/service or business strategy: Renewal can lead to linear or non-linear changes in the firm's business activity. Linear renewal is undertaken through a series of related innovations, path-dependent opportunity pursuits leading to an incremental alteration of product-business activity. In an international context this includes products adaptation to local markets and local R\&D activities. Non-linear renewal pertains to undertakings outside of core business activities that not only alter the product-business offering but also leads to organizational structure changes or business models. A firm that alters its business line structure through additions, cuts, or significant modifications, that enters new or exits old industries, or modifies industries, that fundamentally changes one ore more aspects of its strategy and organization - This is an organization that pursues non-linear renewal. In an international context, such non-linear renewal may be the product of undertaking new (to the firm) activities following local discoveries, drawing on specific localization advantage or the result of local creation of new opportunities. This is not dependent on high-commitment modes of investment in the international location, but rather, the capacity to explore knowledge and exploit it abroad and at home.

We therefore do not overlap non-linear renewal with Agarwal \& Helfat's (2009) discontinuous renewal, since the later is described as an adaptive process to "major changes, such as in technology or customer demand" (p.283) or because a " primary market has matured or is declining" (p.283). We include that, internationally, firms may discern or commit to new business directions in a proactive way, in parallel with linear renewal that "can in most cases be sequenced over time and across different geographic markets"(p.25). 


\section{Renewal and internationalization}

\subsection{Maintaining the firm- (international) environment fit}

Dynamic capability literature increasingly addresses concerns about a competitive sustainability resulting from an organization's evolutionary fit (Ambrosini et al. 2009: 30). Contemporary studies focus on an understanding of what dynamic capabilities are and how dynamic capabilities assist organizations in safeguarding their competitive positioning. This is discussed in literature through the investigation of the role of various activities and the firm's related capabilities, e.g. product innovation, acquisitions, alliances, resource divestment, strategic decision-making, organizational structure, ambidexterity, absorptive capacity, or selection capabilities, as a means to foster dynamic capabilities (Danneels, 2002; Karim \& Mitchel, 2000; Eisenhardt \& Martin, 2000; Ambrosini et al., 2009; Capron \& Mitchell, 2009; O’Reilly \& Tushman, 2008, Zahra \& George, 2002).

A higher order capability, i.e., a capability that is most important for sustained performance, is, to renew capabilities through routines to search and learn. The term "capabilities" there-in defines the key role of strategic management in aligning business to a changing environment through a process of reconfiguration of internal and external organizational resources, skills, and competences.

That is, strategic decision-making is seen as crucially linked to a logic stipulating that the firm maintains the firm-environment fit through search - and learn- routines. For an international firm and for an organization with on-going international aspirations, strategic decisions cannot be disentangled from the international context: The renewal capability reflects anticipated changes in business environments (Teece, 2014) where the firm operates, or aspires to extent to, and the capacity to deal and potentially benefit from them. 
As mentioned, firms with dynamic capabilities are likely to take activity abroad in order to create and capture value, walking through the myriad of possibilities to leverage current - and to build new - capabilities abroad; then a dynamic firm with a solid and adaptable strategy will be able to maintain superior performance (Teece, 2014). The dynamic capabilities literature confirms that firms actively develop new capabilities abroad (Cantwell, 1995; Teece, 2014) so as to "better exploit locally differentiated potentials of foreign resources and opportunities" (Luo, 2002: 49).

The question that remains is: How does this happen? How -in the process of internationalization that involves strategic decision-making - does an organization maintain or develop its renewal capability? How do decisions that relate to internationalization strategy implicate those related to the renewal strategy? Such interest is similar to Cavusgil \& Knight (2015:10) interest: "how do entrepreneurial firms capture, develop, share and optimize knowledge conducive to internationalization and superior performance?"

\subsection{Internationalization and the development of renewal capabilities}

From the IB perspective, firms may renew within their internationalization process by two means: (1) by accessing internationally scattered knowledge and capabilities, and (2) through the impact of learning upon the parent company (Meyer et al., 2009). In the first case, firm's renewal may be simply a consequence of the process of acquisition of complementary local knowledge or capabilities that are needed in order to operate in local markets. The second, learning upon the parent company, is less obvious, yet, more powerful.

Learning, within IB perspectives, is not limited to being a home-market phenomenon. Organizations engage in global learning aiming to exploit "untapped "pockets of technology, market intelligence and capabilities" scattered across the globe (Doz et al., 
2001; Santos, Doz \& Williamson, 2004). Learning from the diversity in the world is seen as a 'must' for the search for new ideas (Chesbrough, 2003) and to avoid "uninspired products" that "are likely to be developed" when firms use the same knowledge reservoirs. Kafouros et al. (2008) studied the moderating effect of internationalization on the relationship between innovation and innovation gains. They demonstrate that, in order to reap the benefits of innovation, firms need to be active in many markets because internationalization affects both innovation capacity and innovation appropriability. Similarly, Leiponen \& Helfat (2010) found that broader horizons in knowledge sourcing provide for successful innovation when measured through the commercialization of innovation, no matter if product or process.

A significant literature stream stresses the impact of internationalization for sustainability of competitive advantage. Yet again, most of them limit their focus on indirect considerations that underpin economic payoffs from international innovation (Kafouros et al. 2008): internationalizing firms may benefit from decreased costs of innovation (Kotabe, Srinivasan \& Aulakh, 2002) by finding R\&D inputs cheaply (Kafouros et al., 2008; Granstrand, Hakanson \& Sjolander 1993); organizations increase innovative capacity through the ability to employ wider ranges of knowledge and capabilities globally available (Kotabe, 1990, Kobrin, 1991, Kafouros, 2006, Kafouros et al., 2008).

More importantly for our purpose, some studies stipulate that international exposure acts as stimulus for innovation (Hitt, Hoskisson \& Kim, 1997); this includes the powerful illustration of the role of the international context in regards to reverse innovation (Zescheky, Widenmayer \& Gassmann, 2014) that can allow for crucial early positioning in new technological trend exploitation. Internationalizing firms are better informed about customers' changing needs (Kafouros et al., 2008) while constantly searching for solutions that increase local responsiveness (Cheng \& Bolon, 1993) and gain local legitimacy (Miller, 2008), as well as on international level. Through the management of distributed innovation, 
we know that networking of firms internationally (Frost \& Zhou, 2005) in addition facilitates the imitation of innovation of other firms, which is in literature is known as one of the main sources of innovation and evidenced particularly in early internationalization (Knight \& Cavusgil 2004). Simultaneously, renewal capabilities develop through these search and change routines, geographic and environmental stimuli (Rosenkopf \& Almeida, 2003) and learning abroad.

\subsection{Internationalization/renewal limitation factors: the firm's strategy}

Despite the theoretical indications and empirical evidence that support the claim that internationalization is important to an organization's innovation and performance, groups such as Kodak, Nortel, Polaroid or AMD serve as examples of international players paying a high price to innovation evolution. Both, IB and strategy literature that discuss potential limits of internationalization indicate that firms can suffer from a disproportionate focus on exploitation as opposed to exploration (Leonard-Barton, 1992; March, 1991), learning myopia (Miller, 2002), knowledge leakage and outgoing knowledge spillover (Fish, 2003; Sanna-Randaccio \& Veugelers, 2007), increased cost of coordination and control (Grandstrand et al., 1993; Fish, 2003), or increased cost of R\&D because of duplication activities (Kafouros, Hashai \& Wang, 2011). When explaining the role of dynamic capabilities and internationalization to the firm's competitive durability, Teece (2014) stresses the central importance of strategy (p. 18). The firm's strategy effectively "will determine which products to make, which customers to target, how to deploy the firm's resources, what the optimal timing will be and how to keep competitors at bay" (p. 17). In an international setting this translates in decisions related to location, timing and venturing modes' strategies. Patterns of internationalization expansion may foster or hinder a 
'searching and learning' (Miller, 2008): Alternatives compete for firm's resource, time and capabilities (Levitt \& March, 1988; Dierickx \& Cool, 1989). This suggests the need to understand not only how renewal capabilities develop, or may be enhanced, in international setting, but also how internationalization strategies inform a firm's renewal strategy or order to create the flexibility needed to survive.

\section{Proposition development}

Our cross-disciplinary literature review has confirmed that renewal capabilities reflect the ability of international firms to search and learn in foreign markets, and to choose the most appropriate way (strategy) in its sector, context and resource availability, due to a need not only 'to do things right' but also 'to do the right things' (Teece, 2014). 'Doing things right', comprises for instance the successfully establishment and operation in different markets, in that on its own, this does not put the firm out of a "complacency set it" risk (Vermeulen, 2005). 'Doing the right thing' denotes the understanding of consequences of various internationalization strategies to renewal, i.e., making decisions that enable the organization to 'navigate' global opportunities with the 'right boat at the right speed'.

On this basis, we now draw on internationalization strategy literature so as to develop propositions that help us conceptualize the internationalization-renewal relationship.

\subsection{The degree of internationalization and renewal: the benefits and limits related to} sensing opportunities and threats 
Internationalization is determined through entrepreneurship acts that involve searching for and sensing of international opportunities that hold a potential to influence an organization's future, and that establish and conduct transactions with(-in) other countries (Beamish, 1990). In this process, the firm is viewed as sensitive to and sensible with market information about cross-border fluctuations that constitute a supply of strategically relevant opportunities, e.g., the positive perception on the Indian market's potential for cost-effective innovations, the Russian market's abundance of IT start-ups or the opportunities for pioneering new business markets in Latin America.

A number of studies suggest that an international presence (geographical diversification with or without physical facilities) plays a stimulus role for sensing abilities (Hitt et al., 1997; Kafouros et al., 2008) by exposing the firm to a wider range of prospects along with added experience (Beamish, 1990; Johanson \& Vahlne, 2009). Having greater opportunities to learn, international firms (committed to continued foreign expansion) were found to improve their ability to innovate (Hitt et al. 1997, Hitt, Hoskisson \& Ireland, 1994, Kafouros et al., 2008) and to appropriate innovation (Leiponen \& Helfat, 2010; Kafouros et al., 2008). Moreover, a double-loop learning associated with experimentation abroad enables firms to better detect environmental changes, helps revise dominant logics and change organizational routines as they discover new ways to leverage capabilities to achieve goals (Miller, 2008).

Routines for searching and learning may also be subject to change. Cisco, a company that between 1993 and 2000 successfully completed 70 acquisitions, -the Cisco way to grow and compete-, then in 2001 reorganized its organizational structure and strategy around organic growth. "The old Cisco devoured startups and raced to build new niche products, the new Cisco wants to create fewer, more versatile products internally" (Thurm, 2003). In 2013, CNN reporters: "Cisco's reinvention is paying off” (Pepitone, 2013) while John Chambers, 
Cisco's CEO since 1995, likes to explain how Cisco's global reach allowed the company to spot global trends as they emerge.

We therefore acknowledge that international diversification has the potential to raise the likelihood of effective refreshment of capabilities, with international diversification having a positive influence on firm's renewal capabilities. However the relationship is not always that straightforward: Miller (2008) found no linear relationship between the level of internationalization and experiential search while the fundamental relationship between multinationality and performance has not always been linear and positive in empirical studies but sometimes negative, U-shaped, inverse U-shaped or sigmoid (Hennart, 2007, 2011; Contractor, Kundu \& Hsu, 2003). Schilke (2014) found that the relationship between dynamic capabilities and competitive advantage is strongest under intermediate levels of dynamism and weaker when dynamism is low or high (p. 179). Geographical diversification conveys dynamism in the environment.

There may be several explanations for this. One reason may be that firms enter foreign markets with the primary goal to exploit their home based advantages (marketseeking motives), thus having little direct incentives to modify firm's attributes as its longterm goals in this process (Song \& Shin, 2008; Schleimer \& Pedersen, 2014; Hennart, 2007). Local learning may accordingly be limited to searching and learning how to best adapt to a local market, or how to reach different local market segments. Such firms, usually endowed with technological capabilities, need to rely on strategic searching and learning at home and, as Song \& Shin (2008:291) suggest, have little motivation to outsource and acquire knowledge for strategic renewal in host markets. Or, if part of strategic searching and learning takes place abroad, this is usually organized around certain subsidiaries only but that have been assigned this strategic role (Bartlett \& Ghoshal 1986). 
Other explanations include scarcity of resources and attention to performing two types of activities, leveraging and building capabilities, at the same time. Managerial resources may be a source of growth constraint, known as "Penrose effect". In the internationalization process this may happen when the firm reaches a high degree of internationalization diversity or when internationalization happens simultaneously or fast. When the firm faces increased operational complexity attributed to a multiplicity and diversity of local contexts that the firm needs to address and adapt to, it may reach its "cognitive limits to resources that determine what [it] can and cannot do" (Meyer, Mudambi \& Narula, 2011:244). Consequently it may be difficult for the firm to develop renewal capacities at the same time. Similarly, when the firm is reaching simultaneously or fast to diverse markets, it needs to concentrate resources and attention to dealing with new and various ambiguities (March, 1991) and a range of liabilities of foreignness ${ }^{3}$. Coordination and governance costs may also exceed the benefits of scope (Contractor et al. 2003)

In other words, when the experience abroad is characterized by high complexity due to operational challenges (due to "multiple embeddedness") it "can overwhelm managers, leading to an inability to transform experience into meaningful learning" (Eisenhardt \& Martin, 2000: 1115; Meyer et al. 2011: 235). Otherwise stated, when cognitive abilities are stretched (Miller, 2008), the firm assimilates only a limited amount of information (Cohen \& Levinthat, 1990) or it may experience diminishing returns to accommodate the process of adaptation (Dierickx \& Cool, 1989).

Considering that the capabilities of the internationalizing firms stem, among others, from the diversity of contexts in which they operate (Teece, 2014), and considering, on the other hand, what Meyer and colleagues (2011) refer to as the "cost of multinationality" (p.244) related to managing complexity that comes with high degrees of international

\footnotetext{
3 This may be a temporal situation. Here dynamism is related to the speed and the scale of internationalization
} 
diversity, we advance that, an organization that aspires to learn in foreign markets is more likely to develop renewal capabilities abroad at moderate levels of internationalization diversity rather than high levels. The cost of multinationality embodies the difficulty to identify and correct problems (p.246) when the organization achieves high levels of complexity ${ }^{4}$. This assumption is also in line with studies concentrated on the multinationality/performance relationship that found a curvilinear effect with a threshold of diversity past which the performance may be hampered (Contractor et al. 2003, in the case of knowledge-based firms) because of the limits to the capacity of managers to successfully cope with increased complexity (Contractor et al., 2003).

We posit:

Proposition 1. Associated to the sensing stage: There is an inversed " $U$ " relationship between the degree of internationalization diversity and the development of a firm's renewal capability

4.2. Internationalization strategic decisions and renewal: the ability to seize opportunities and apply them

Literature also stipulates that internationalization process capabilities are contingent upon the firm's ability to draw on location opportunities, to time foreign expansion and to decide upon the foreign venture mode. All of these are decisions with an objective of achieving some form of 'success', as defined by the organization. Teece (2014) discusses the relationship between internationalization and dynamic capabilities, including decisions regarding internationalization process, yet empirical studies that would directly link the

\footnotetext{
${ }^{4}$ Managerial resources constraints is also known as "Penrose effect"
} 
internationalization process to renewal capabilities are not, to our knowledge, available. We thus continue to develop our discussion linking literature streams that pertain to the role of location, timing to internationalization and venture mode strategies, in the following section, to support this contribution.

\subsubsection{Location related decisions and renewal}

Within firm-level data studies, location decisions have been considered as subject to an objective, calculative methodology or as a subjective, managerial act. Market size, wage rates, transport costs, cultural distance, institutions, technology factors, government policy, and corporate experience, as well as industry related factors, have all been regressed against location related decision (Woodward \& Rolfe, 1993; Barkema, Bell \& Penning, 1996; Chung, 2001; Zhou, Delios \& YuYang, 2002; Davidson, 1980; Zahra, Ireland \& Hitt 2000; Kafouros, Buckley \& Clegg 2012). Amongst important observations from this literature, our conceptual investigation into capability- seeking investment is interested in that location decisions enhance responsiveness to global opportunities through the experience that the firm gains (Davidson, 1980; Johanson \& Vahlne, 1977). Knowledge seeking variables have high explanatory power for location related decisions (Chung \& Alcacer, 2002, Ambos, 2005) and local embeddeness is associated with an internationalization strategy that allows for better learning here-in (Katila \& Ahuja, 2002).

A research and development climate supported by the government, an entrepreneurial environment, growing markets, a stable (or unstable) regulatory environment, and favorable (or unfavorable) intellectual property (IP) regimes are examples of country level factors that have been considered important in the location literature. Rugman \& Oh (2012) and Suder 
(2013) add that location choice decisions are complemented by region- specific advantages, with regionalization and economic integration enhancing firms' market reach.

Location advantage is indeed of particular importance in light of the interaction of the MNE with home country capabilities and host country capabilities (Cantwell, 2014). Yet, all being equal, the location advantage is of little explanatory power to a firm's ability to maintain competitiveness simply because they are available to both domestic and multiple internationalizing firms. Teece (2014: 27$)$ suggests that only if the firm is able to access local opportunities and learn and develop knowledge "in way that others can not (or fail)", particular location advantages become relevant for competitive sustainability playing a role to firm's renewal. That is, capability building and competitiveness relies on the ability of the firm to orchestrate complementary internal and external networks (Cantwell, 2014:3). Accepting that "at least from a theoretical viewpoint [..] capability building relies on a nexus of reciprocal relationships that are less and less well defined by the boundaries of the ownership" (Cantwell, 2014:3), neither will location advantages nor a large number of strategic (to firm) locations in which the firm operates fully explain its renewal capability. This is because these strategic markets simply cannot substitute for the ability (and sometimes the motivation) of the firm to absorb the knowledge available in those locations (Kafouros et al. 2012; Hennart, 2007).

To search and learn in a way that others cannot imitate in a particular environment, scholars have found local (or regional) embeddedness to be critical. When organizations seek to enhance capabilities, they need access to networks and settings. Firms, literature acknowledges, learn and locally seize opportunities that have the potential to impact their long-term prospects (Teece, 2007; Buckley \& Casson, 2009) to the extent to which they have an established presence, as an ongoing engagement with ecosystem partners and relevant networks (Katila \& Ahuja, 2002; Rosenkopf \& Almeida, 2003; Teece, 2014). Kafouros et al. 
(2008) and Kafouros et al. (2011) demonstrate additionally that the variations in the ability to seize globally dispersed knowledge from the internationalization process not only depends on the structure of network subsidiaries (geographical distribution), but on the extent of firms' local embeddedness and the acquisition of sticky knowledge and its transfer as a unique business resource.

Putting it differently, while there must be a set of location advantages that convey potential for augmenting firms' ownership advantages, the degree of this augmentation will depend on the firm's local network embeddedness. And if a moderate degree of internationalization diversity were to be desired from a capability sensing perspective- as we advance in our first proposition- a high level of local embeddedness would increase the seizing likelihood in these locations. Through embeddedness, subsidiaries can benefit from local and inter-firm spillovers (Rosenkopf \& Almeida, 2003), can draw on externalities that are not accessible by firms with limited depth (Kafouros et al., 2012) while achieving a threshold of knowledge concentration and complexity to be able to successfully integrate these externalities in operations (Kafouros et al., 2012; Kotabe, Dunlap-Hinkler, Parente \& Mishra, 2007). The depth of firm internationalization becomes a measure of firms' establishment abroad rather than its commercial presence.

We therefore propose:

Proposition 2. Associated to the sensing-seizing stage: Local network embeddedness mediates the relationship between location advantages and the development of a firm's renewal capability.

\subsubsection{Timing related decisions (speed behavior) and renewal}


The consideration that internationalization is a key component of MNE survival is enhanced yet again by literature's consideration of timing (or 'speed'), split into two main scholarly streams that build upon the two most relevant contemporary internationalization theories.

The Uppsala school of internationalization (Johanson \& Vahlne, 1977, 2009) proposes an experiential, learning-based model of international expansion that accounts for the liability of foreignness. Knowledge, especially market knowledge, is fundamental to firm internationalization; knowledge is accumulated via existing activities (operations) over time. Since 2009, the model also suggests that knowledge may be acquired with some difficulty due to a liability of foreignness and outsidership of business networks. The business environment is viewed as "a web of relationships, a network, rather than as a neoclassical market with many independent suppliers and customers" (2009:1411). Firms strive to build knowledge through relationships, and enter networks abroad where opportunities arise and can be leveraged, i.e. through collaboration with a new partner already having a position on the market. Learning remains a mechanism of internationalization; its speed (of deployment) may remain moderate and is usually embedded in the relationship building around opportunities (Johanson \& Vahlne, 2009).

Within the context and logic of a pro-active and explicit renewal strategy through internationalization, we would expect a suitably time-sensitive process. This is where the second stream of research becomes insightful for our analysis, where scholars mainly focus on time (and even more so: speed) related to the international expansion. Speed has been directly addressed by the international new venture (INV) literature, later also referred to as 'born global' (BG). Oviatt \& McDougall (1994) observed that certain business organizations "seek to derive significant competitive advantages from the use of resources and the sale of outputs in multiple countries" (1994:49) just from inception. Time/ speed is referenced as the 
period between a company's foundation and its first venture abroad. Yet, as Casillas \& Acedo (2013) note, time deals with the pre-internationalization period rather than with the internationalization process in itself. Yet it factually is the speed of early internationalization, time being operationalized by only two discrete points (inception and first move abroad), that is particularly brief and that sets the scene for speedy knowledge acquisition and a trigger for survival: While typically disposing of limited tangible resources, INVs are seen as inherently innovative, entrepreneurial, and dynamic (Knight \& Cavusgil, 2004) with a strategy set to discover, link and take advantage of business opportunities in multiple countries (Oviatt \& McDougall, 1994).

One characteristic of young firms that lack the administrative heritage of larger, older competitors (Knight \& Cavusgil, 2004) is flexibility, an attribute to achieve organizational and entrepreneurial skills. By consequence, dependence on internationalization to develop new capabilities is high (Sapienza, Autio, George \& Zahra, 2006). Internationalization "creates an imprint for adaptability to certain environments and an internal receptivity to continual change" (Sapienza et al., 2006).

Given flexibility and time-sensitivity, firms internationalizing quickly - as considered by prevailing academic theory- are more prone to access knowledge that determines their renewal than larger, older, traditionally internationalizing firms following a market leaning stage model. Yet, if we were to rely on the extant INV literature, this does not clearly establish the extent to which those firms internalize globally distributed external knowledge or capabilities, how they further develop abroad, or how they learn and build on their absorptive capacity that would further allow them to develop new capabilities (Zahra, 2005). Also, most literature, focuses on BGs' internationalization via trade and 'early export to multiple countries' rather than for capability-seeking internationalization pursuits through investments. It is thus not clear whether or how a correlation between speed and 
embeddedness would prevail. Do early internationalizing firms share a set of traits that might be those that Vahlne \& Johanson (2013) referred to as internationalization capabilities when talking about the ability of the firm to "approach and develop different markets and locations under different circumstances" (p.203)? If so, how does their post-entry reflect on firms' ability to thrive over time, renew and survive? In addition to these questions that need further inquiry in literature: It appears that older firms need to engage deeper into internationalization and focus more on the frequency of renewal than younger firms in their early stages of internationalization.

Theoretical insights suggest that the dynamics of the internationalization of INVs/ BGs leads to their performance (Knight \& Cavusgil, 2004; Oviatt \& McDougall, 2005); yet empirical studies on their survival rate are scarce and provide indications rather than evidence at this stage, thus fit for conceptualization rather than theory- development. No linear relationship between early internationalization and growth or survival, as proposed by Sapienza et al. (2006), has been empirically supported. Rather, early internationalization and performance take a U or S shape relationships (Schueffel, Amann \& Herbolzheimer, 2011). Mudambi \& Zahra show that INVs, though confronted with two liabilities of newness and outsidership at the same time, "have similar odds of survival as other modes of foreign entry" (2007: 348).

It is important to note that a comparison of a firm's stage- internationalization process (an intra-stages continuous process) to the time elapsing between naissance and venture abroad (an intra-stage change) versus its performance or survival can be misleading. Rather, we are interested in speed of access to evolving, dynamic knowledge. Also, let us note that there are three types of speed in the international process: change in international commercial intensity (e.g., export driven); commitment of foreign resources; breadth (dispersion) 
throughout international markets (Casillas \& Acedo, 2013). Each potentially plays a different role in a firm's performance.

In this paper, we are interested in that the internationalization models differ in their view on speed-behavior vis-à-vis internationalization mode, degree (depth), and breadth. Dynamic capabilities and organizational learning perspectives can significantly advance the understanding of such drivers of speed coupled to IB theory. We advance that if one model may be a linear, experiential-based internationalization model and another, opportunity based $^{5}$, a non-linear model of internationalization where speed is important, under condition of resource availability, then renewal will result in similar linear/ non-linear trajectories according to the motives behind these strategies, which are market based vs. opportunity based internationalization. Linear internationalization will increase the likelihood of incremental renewal (the firms learn in markets and adapt product offering to expectations, which may feed into renewal objectives). Non-linear internationalization increases the likelihood of non-linear opportunistic renewal (the firm takes on opportunities where they arise and feed into objectives while becoming increasingly exposed to different markets). We therefore propose:

Proposition 3a. Associated to the seizing-application stage: A stage model of expansion (linear), where the speed of internationalization is calibrated upon market learning, increases the likelihood that the firm will develop routines for, and engage with, linear renewal (i.e. increases the likelihood that the firm will apply knowledge to extend on the core business).

\footnotetext{
5 We do not equate opportunity based internationalization with INVs or BGs since, as mentioned, their speed to internationalization regards pre-internationalization phase. Moreover, INVs/ BGs may internationalize via export (trade) and licensing modes that do not necessarily provide great learning opportunities as oppose to the FDI modes. Rather opportunity-based internationalization refers to process in which the speed of internationalization is untangled from the market learning condition.
} 
Proposition 3b. Associated to the seizing-application stage: An opportunity-based (nonlinear) model of expansion where the speed of internationalization is calibrated upon opportunity discovery increases the likelihood that the firm will develop routines for, and engage with, non-linear renewal (i.e. increases the likelihood that the firm will apply knowledge to undertake outside the core business).

It is worth noting here that we do not imply that a firm's internationalization approach to speed would be exclusive or could only be described by one approach or another. For one, non-linear trajectories are likely if resources are available and after the acquisition of internationalization knowledge. Also, a firm that internationalizes primarily based on a stage model may become increasingly entrepreneurial in its knowledge acquisition over time to ensure survival. Therefore our time-path differentiation rather cuts on the importance given to the speed-behavior in the process of opportunity discovery and development abroad.

\subsubsection{Venture modes decisions and renewal}

The third characteristic of the internationalization process in our focus is the way in which firms venture into foreign markets: As prescribed in IB literature, we make a distinction based on the degree of ownership and control that various modes provide to the focal firm, in which greenfield investments, acquisition and equity modes of Joint ventures are WOS (wholly owned subsidiary)- types of FDI that provide full or partial ownership and control/internalization of key ownership advantage; this is what we shall focus on here, versus non-equity modes such as licensing/franchising, R\&D contracts, etc., where the ownership and/or control of ownership advantage are externalized. For the purpose of our analysis, we then distinguish WOS/knowledge acquisition modes into organically (e.g. 
greenfield investment or wholly own subsidiaries) or collaborative, i.e.,, in agreements with local firms (e.g. acquisitions or joint ventures). Literature is dominated by studies developed upon internalization theory (Zhao, Luo \& Suh, 2004): 'uncertainty' is viewed as central in selecting the right governance form for foreign activities, with direct impact on transaction cost. Uncertainty is shown as the inability to predict future events, usually because of the volatility of the host environment (Zhao et al., 2004) measured through country risk. Internal uncertainty is related to the difficulty to accurately evaluate an agent's performance through readily available output, commonly measured by international experience and cultural distance (Zhao et al., 2004).

Firms aiming to exploit superior knowledge in foreign markets for renewal purposes are expected to prefer organic modes of establishment because of minimal costs of knowledge transfer and exchange hazards associated with appropriability concerns (Williamson, 1981; Slangen \& Hennart, 2007). Yet, when firms lack host-country knowledge or other essential knowledge to successfully establish abroad, they venture through collaborative modes such as acquisitions to improve access to locally embedded knowledge. The problem related to appropriability hazards is there-in mitigated through decisions related to the level of ownership; some acquisitions can be partial or totally owned.

However, investments in local knowledge or strategic capabilities with a long-term perspective possess a quality that makes the cost calculative application particular: In addition to the external uncertainty that results from the volatility of host environmental conditions (with associated transaction costs), there is uncertainty associated with returns on the investment for desired knowledge or capability. Investments directed to renewal often do not deliver immediate returns, but rather have an associated expectation to become critical in the future. Such uncertainty may be exacerbated by the liability of foreignness and/or the liability of outsidership (Johanson \& Vahlne, 2009). 
Moreover, while some opportunities are recognized or strategically created by firms, others are embodied in relationships (Ghauri, Hadjikhani \& Johanson, 2005). Consequently, the firm only has a partial influence on the pace and geography of opportunity arrival. Transaction cost may thus become unsuitable for explaining a firm's diversification or the governance form adopted for its certain foreign investments: Transaction cost theory, with some reliance on opportunism and the minimizing costs associated with incentive conflicts, in this context falls short of explaining firm heterogeneity, coordination type problems, and dynamic capabilities (Winter, 1991; Langlois, 1992; Kogut \& Zander 1992; Teece, 2014), and needs expansion.

Interestingly, the idea that investment in knowledge regeneration is fundamental for firms whose product portfolio approaches maturity (Lane and Lubatkin, 1998) has deep roots in evolutionary economics and is further nurtured by the dynamic capabilities literature. Literature stresses the importance of cost for communication, coordination, and combinations as a primary metric for the investment mode (Kogut \& Zander, 1992, 1993), value creation and capture (Pitelis \& Teece, 2010). The most appropriate investment ventures, from this perspective, would be the ones that foster the co-creation of cross-border value (Pitelis \& Teece, 2010).

Meyer et al. (2009) propose a framework for foreign mode choices in which firms are driven not by cost minimization but by "the aim to maximize the value created by transaction", i.e., the most value-creating choice in the long run (p. 558). They classify modes by entrants' access to local resources into 'high, medium, and low augmenting'. Meyer et al. (2009) suggest that overall, when knowledge is important, collaborative modes are preferred. In that, full or partial acquisitions stand for high resource-augmentation modes. These modes provide access to both complementary resources as well as organizationally embedded knowledge. Organic modes, such as greenfield ventures, run with local professionals and 
partial acquisitions represent medium-access modes because they provide a way to tap local resources while allowing for the exploitation of competitive advantages. Greenfield branches with expatriates offer only limited learning: if a firm internationalizes through greenfield investments, probably focusing on leveraging its superior knowledge or capabilities, then the firm will have marginal contact with local market actors (other than distributors or marketing partners) compared to other entry modes' access and thus, limited learning. The firm will incrementally renew through adaptation and capability recombination in order to gain market share.

Conversely, if the firm acquires a local enterprise or build a local joint venture then the firm will be exposed to embedded learning. The target firm may have an already establish product (sometimes, the acquisition reason) but this firm's capabilities will still be subject to learning for the parent firm. Vermeulen (2005) demonstrates that acquisitions made on regular basis help refresh views and diminish the risk of learning myopia. Other times, the focal firm will build partnerships with locals in order to co-develop new business lines or new products, that is, to engage a non-linear renewal: Non-linear renewal is likely to emerge when the firm invests in world regions through collaborative modes. In a nutshell, establishing into world regions through collaborative knowledge-acquiring modes (acquisitions or joint ventures) increases the likelihood of non-linear renewal, provided availability of necessary resources, more than investing into world regions through organic modes (greenfield investment).

Proposition 4a. Expanding abroad primarily through organic knowledge-acquiring modes (greenfield investment) increases the likelihood that the firm will develop routines for, and engage with, linear renewal (i.e. increases the likelihood that the firm will transform by extending on the core business). 
Proposition 4b. Expanding abroad primarily through collaborative knowledge-acquiring modes (acquisitions or joint ventures) increases the likelihood that the firm will develop routines for, and engage with, non-linear renewal (i.e. increases the likelihood that the firm will transform by extending on the core business).

\section{Discussion and conclusion}

Taken together, current strategic management and IB literature suggest that firms search and learn abroad in order to maintain competitive advantage. Knowledge and capabilities are pivotal elements of renewal processes, since they are considered strategically the most significant resource of firms and a source of competitive advantage. Through internationalization, the firm increases its ability to sense, and the opportunity to seize and apply globally scattered knowledge and capabilities and hence the competence to arbitrate globally spread opportunities.

Our investigation on how internationalization allows for the development of renewal capabilities reveals the potential and limits of sourcing knowledge and capabilities in foreign markets to the development of renewal capabilities at different stages: sensing, seizing, and applying (transforming). We also investigate how decisions related to internationalization strategies impact firm's renewal strategies.

We distinguish between renewal capabilities- the ability to continuously search and learn and refresh capabilities, including dynamic capabilities (searching and learning routines)- from the renewal strategies. Renewal strategies - linear vs. non-linear renewalreflects strategic decision about how far from the core business activity the firms will want to invest its efforts to searching and learning. Fundamentally, renewal is the byproduct of 
changes in routine to search and learn, as for example, shifting focus from external to internal growth, or vice versa. Or navigating between renewal strategies, meaning changing the locus of learning, for example learning 'close' or learning 'long', gradually developing the core business or experimenting into new business areas. One refers to the process, the other to the content of renewal. Both renewal capabilities and renewal strategies interplay with the firm's internationalization strategies.

While several studies point to the benefit of internationalization to the performance sustainability of the firm, thus indirectly to the renewal capability, and suggest such relationship to be positive (Delious \& Beamish, 1999; Allen \& Pantzalis 1996; Tang \& Tickoo 1999; Kafouros et al. 2012) others found it to be negative, insignificant, U-shaped, inverted U-shaped or sigmoid (Hennart, 2007, 2011; Contractor et al., 2003). Our analysis suggests a curvilinear, inversed $U$ relationship between international diversity and the renewal capability of the firm. We posit that firm's international diversity plays an instrumental positive role in the development of renewal capabilities when the firm is internationalized. We find however that, when a firm starts to internationalize it faces challenges related to newness and so it focuses efforts on gaining knowledge of (a) how to successfully operate abroad, (b) how to gain legitimacy and (c) how to manage units operating in (or with) different institutional environments, depending on entry mode. This is particularly true if the internationalization happens simultaneously or fast. Consequently, the firm has little resources (financial, time and attention) and incentives to consider such new environments from a capability renewal perspective, except if this was the primary strategic motivator. Also, few markets may not be enough to change a firm's perspective, or perfectly aligned or similar markets may provide few unique learning opportunity. Indeed, Kafouros et al. (2008) show that firms need a sufficient degree of internationalization in order to (d) reap rewards from innovation, or what we posit as strategic renewal advantage. Conversely, but 
with similar effects, a firm operating in large number of markets is prone to encounter operational difficulties: "In the face of increasing complexity, bounded rationality reinforces organizational inertia" (Meyer et al., 2011: 246), making so difficult the development of renewal capabilities, since "is more difficult to identify and correct problems".

Our second goal was to discuss the role of different internationalization decisions to the renewal strategy. Our theoretical analysis suggests that embeddedness in local environments and the engagement with local ecosystems are more important than selecting the right locations from a renewal perspective. This is because location advantages are alike exploitable by domestic firms and other internationalizing firms thus having little relevance to firm's learning and knowledge development advantages unless the firm is able to leverage local advantages in a way that others cannot. While location selection has been repeatedly called for its importance to a firm's capability building, several studies insist on the ability to draw on local (or regional) advantages (Kafouros et al. 2012). Therefore instead of exclusively focusing on where knowledge and capabilities are, managers may focus on how local capabilities can be seized and applied in a way that others cannot. Assuming that firms select locations that are relevant for learning, to the extent they consider internationalization to renewal, we posit that local embeddedness is positively associated with a firm's renewal capability.

By investigating the timing of internationalization relationship with the renewal strategy we draw a parallel relationship between the internationalization learning-based strategy and linear renewal and between the opportunity-based strategy to internationalization and non-linear renewal odds. The first time-path strategy to internationalization, initially explained in the traditional Uppsala model, suggests a progressive -market learning commitment- mechanism driving firms' international expansion strategy. Since learning is path depended in this view, so the renewal strategy will be, that is, firms investing abroad in a 
path-depended, progressive way will develop routines for linear renewal. Conversely, if firms take an opportunity-based strategy to internationalization where the speed of internationalization is important, the firm will likely develop routines to non-linear renewal, under the condition of resource availability. Opportunities taken abroad will expand the firm's learning boundaries from knowledge and capabilities that are close to firm's core business to those that are new to the firm. If confirmed, the immediate managerial implication is that, while the two internationalization strategies are not exclusive, the firm should be aware of the implications the two have on renewal. This allows calibrating how resources are spent abroad for the renewal strategy the firm envisages.

Our final analysis centered on the interplay between venture mode options and renewal strategies. Similarly to internationalization timing strategies, various venture modes plays the role of antecedents for renewal strategies. Organic modes of expansion, that is, WOS modes that obtain knowledge organically, increase the likelihood that the firm will engage with linear renewal since the firm has limited exposure to, and little interaction with, local actors, thus creating a barrier to learning outside the core business, except when their survival is at risk. Conversely, if the firm adopts what we called collaborative knowledgeacquiring WOS modes of expansion, the likelihood that the firm will experience outside the core activity increases. Just as in the previous discussion, while the two venture mode strategies are not exclusive, the firm in this models has the capacity to adjust its learning objectives abroad to the potential and limits of different venture modes, aligned thus to the process of knowledge and capability renewing abroad.

The contribution of these findings to literature is three-fold: First, the dynamic capabilities view is advanced through proposition conceptualizing the relationship between firm's internationalization and dynamic capabilities. Teece (2014) proposed a dynamic capabilities-based entrepreneurial theory of the multinational enterprise. Our propositions 
take this theoretical development into account. Here we extracted a particular viewpoint, in that renewal has a relationship with internationalization and that this relationship is not necessarily linear. We discuss how the international context and strategies of internationalization play roles in the development of renewal capabilities and as antecedents to renewal strategies of the firm. We believe that more (empirical) analyses are needed to understand the process of renewal in an international context. Empirical studies may test some of the propositions. Our aim goes beyond merely adding to the MNE subsidiary learning literature, with a more holistic approach towards renewing and applying internationally. This pertains to business models that concurrently capitalize on the firm's cross-border operations and its higher-order routines for renewal in order to shift from a sustainability strategy to a strategy that is sustainable.

Secondly, we add to the strategic renewal literature. In coherence with Dougherty (1992), we studied a practice that produces renewal, namely internationalization, to better understand how firms extend and exploit necessarily knowledge to craft viable transactions in a globalized market. Through internationalization, firms source and refresh knowledge and capabilities that have the potential to substantially affect its long-term prospects. We suggest that international diversification benefits the evaluation of risk associated with the new geographical markets, and the risk-benefit relationship associated with future business markets. Furthermore, we propose an emerging taxonomy of forms of internationalization that allow for effective renewal process, distinguishing between linear and non-linear renewal.

Thirdly, we respond to previous criticism that internationalization studies have disproportionally focused on the competitive advantage of exploitation as the strategic motivation for geographic diversification, as opposed to strategic asset exploration (Johanson \& Vahlne, 2009; Pedersen \& Shaver, 2011). We emphasize the role of internationalization on 
capability extension, with reconfiguration complementing exploration purposes. While there is theoretical and empirical evidence for the role of internationalization to innovation, innovation gains, and performance, no study previous to this paper, to the best of our knowledge, demonstrated how internationalization could benefit renewal capabilities of a firm in a fine-grained analysis that accounts for the various possible means of internationalization.

Finally, we posit that knowledge and capabilities sourcing decisions rely on an overall strategy aimed at capability development, since learning is superior when acquired through repeated routines: Here we drew on behavioral/ learning and dynamic capabilities work that suggests the benefit of repeated routines, when these routines involve the rejuvenation of firms' attributes such as goals, products, and policies that have the potential to reposition the firm in its competitive environment, towards the institutionalization of renewal practices. Since renewal routines and internationalization decisions are interrelated in some situations, such as in the venture mode abroad, we stipulate that the internationalization venture mode decision comes as an extension or application of the overall organizational renewal activities. This explains why some organizations that rely on collaborative development and follow this practice across borders are better organized for renewal and renewal appropriation in the long term than others.

We developed a set of four propositions that set an important framework for future research. These propositions can be tested in at least two ways. First, we suggest in-depth inquiry through the development of case studies of large multinational corporations older than 20 years to allow for a longitudinal investigation of the extent to which internationalization and organizational capabilities for renewal are linked to the capability to develop new capabilities? Also, to what extent do firms thus raise the odds of survival? What resources allow INV -type firms to engage in the non-linear renewal, and what motivates 
Uppsala- type firms to divert from a path of linear renewal? Finally, an empirical test of the model on a large panel database may further consolidate its value for future studies. 


\section{References:}

Agarwal, R., \& Helfat, C.E. (2009). Strategic Renewal of Organization. Organization Science, 20(2), 281-293.

Ambos, B. (2005). Foreign direct investment in industrial research and development: a study of German MNCs. Research Policy, 34(4), 395-410.

Ambrosini, V., Bowman, C., \& Collier, N. (2009). Dynamic capabilities: An exploration of how firms renew their resource base. British Journal of Management, 20(S1), S9-S24.

Baden-Fuller, C., \& Volberda, H.W. (1997). Strategic renewal how large complex organizations prepare for the future. International Studies of Management and Organization, 27(2), 95-120.

Barkema, H.G., Bell, J.H., \& Penning, J.M. (1996). Foreign Entry, Cultural Barriers, and Learning. Strategic Management Journal, 17,151-166.

Barker III, L.V., \& Duhaime, I.M. (1997). Change in the turnaround process. Theory and empirical evidence. Strategic Management Journal 18 (1), 13-38.

Bartlett, C.A., \& Ghoshal, S. (1986). Managing across borders: The transnational solution. Random House Great Britain second edition.

Beamish, P.W. (1990). The Internationalization Process for Smaller Ontario Firms: A Research Agenda. In: Alan. M, Rugman. Research in Global Strategic ManagementInternational Business Research for the Twenty-First Century: Canada's New Research Agenda. (Ed.). Greenwich: JAI Press Inc, 77-92.

Bertrand, O., \& Mol, M.J. (2012). The antecedents and innovation effects of domestic and offshore R\&D outsourcing: The contingent impact of cognitive distance and absorptive capacity. Strategic Management Journal, 34(6), 751-760.

Buckley, P.J, \& Casson, M.C. (2009). The internalization theory of the multinational enterprise: A review of the progress of a research agenda after 30 years. Journal of International Business Studies, 40(9), 1563-1580.

Cantwell J. (1995). Innovation in a global world. Globalization does not kill the need for national policies. New Economy, Institute for Public Policy Research, 2(2), 66-70.

Cantwell J. (2014) Revisiting international business theory: a capabilities-based theory of the MNE. Journal of International Business Studies, 45:1-7.

Capron, L, \& Mitchell, W. (2009). Selection capability: how capability gaps and internal social frictions affect internal and external strategic renewal. Organizational Science, 20(2), 294-312.

Casillas, C.J., \& Acedo, F.J. (2013). Speed in the internationalization process of the firm. International Journal of Management Review, 15(1), 15-29. 
Cavusgil, T. S., \& Knight, G. (2015). The born global firm: An entrepreneurial and capabilities perspective on early and rapid internationalization. Journal of International Business Studies, 46, 3-16.

Cheng, J.L.C., \& Bolon, D.S. (1993). The Management of Multinational R\&D: A Neglected Topic in International Business Research. Journal of International Business Studies, 24(1), 1- 18.

Chesbrough, H.W. (2003). The era of open innovation. MIT Sloan Management Review, 44, $35-41$.

Chung, W. (2001). Identifying Technology Transfer in Foreign Direct Investment: Influence of Industry Conditions and Investing Firm Motives. Journal of International Business Studies, 32(2), 211-229.

Chung, W., \& Alcácer, J. (2002). Knowledge Seeking and Location Choice of Foreign Direct Investment in the United States. Management Science, 48(12), 1534-1554.

Cohen, W.M., \& Levinthal, D.A. (1990). Absorptive capacity: a new perspective on learning and innovation. Administrative Science Quarterly, 35, 128-152.

Contractor, F., Kundu, S., \& Hsu, C.C. (2003). A three-stage theory of international expansion: the link between multinationality and performance in service sector. Journal of International Business Studies, 34(1), 5-18

Crossan, M.M., \& Berdrow, I. (2003). Organizational learning and strategic renewal. Strategic management Journal, 24 (11), 1087-1105.

Danneels, E. (2002). The dynamics of product innovation and firm competences. Strategic Management Journal, 23(12), 1095-1121.

Davidson, W.H. (1980). The Location of Foreign Direct Investment Activity: Country Characteristics and Experience Effects. Journal of International Business Studies, 11(2), 9-22.

Delios, A., \& Beamish P. (1999). Geographic scope, product diversification and the corporate performance of Japanese firms. Strategic Management Journal, 20(8), 711-727

Dierickx, I., \& Cool, K. (1989). Asset stock accumulation and sustainability of competitive advantages. Management Science, 35, 1504-1511.

Dougherty, D. (1992). A practice-centered model of organizational renewal through product innovation. Strategic Management Journal, 13(S1), 77-92.

Doz, Y., Santos, J., \& Williamson, P. (2001). From global to metanational: how companies win in the knowledge economy. Boston: Harvard Business School Press. Available at:

http://www.vedpuriswar.org/book_review/From\%20global\%20to\%20metanational.P $\mathrm{DF}$ 
Eisenhardt, K., \& Martin, J.A. (2000). Dynamic capabilities: what are they? Strategic Management Journal, 21(10-11), 1105-1121.

Fisch, J.H. (2003). Optimal dispersion of R\&D activities in multinational corporations with a genetic algorithm. Research Policy, 32(8), 1381-1396.

Frost, T.S. \& Zhou, C. 2005. R\&D co-practice and |[1squo]|reverse $\mid[$ rsquo] $\mid$ knowledge integration in multinational firms. Journal of International Business Studies, 36, 676687.

Ghauri, P.N., Hadjikhani, A., \& Johanson, J. (2005). Managing opportunity development in business networks. Palgrave Macmillan, April 2006, ISBN: 978-1-4039-4769-7.

Gioia, A.D, \& Chittipeddi, K. (1991). Sensemaking and sensegiving in strategic change initiation. Strategic Management Journal, 12(6), 433-448.

Granstrand, O., Hakanson, L., \& Sjolander, S. (1993). Internationalization of R\&D - A survey of some recent research. Research Policy, 22, 413-430.

Gulati, R., Puranam, P. (2009). Renewal through reorganization: The value of inconsistencies between formal and informal organization. Organization Science, 20(2), 422-440.

Hennart, J-F. (2007). The Theoretical Rationale for a Multi- nationality-Performance Relationship. Management International Review, 47 (3), 423-452.

Hennart, J-F. (2011). A theoretical assessment of the empirical literature of the impact of multinationality on performance. Global Strategy Journal, 1, 135-151.

Hitt, M.A., Hoskisson, R.E., \& Ireland, D.R. (1994). A mid-range theory of the interactive effects of international and product diversification on innovation and performance. Journal of Management, 20(2), 297-326.

Hitt, M.A, Hoskisson, R.E., \& Kim, H. (1997). International diversification: Effects on innovation and firm performance in product-diversified firms. Academy of Management Journal, 40(4), 767-777.

Huang, Y-F. (2009). Strategic renewal within an information technology firm: Exploration, exploitation and corporate venturing. International Journal of Entrepreneurial Behavior and Research, 15(5), 436-452.

Huff, O.J., Huff, A.S., \& Thomas, H. (1992). Strategic renewal and the interaction of cumulative stress and inertia. Strategic Management Journal, 13(S1), 55-75.

Johanson, J., \& Vahlne, J.E. (1977). The Internationalization Process of the Firm-A Model of Knowledge Development and Increasing Foreign Market Commitments. Journal of International Business Studies, 8(1), 23-32.

Johanson, J., \& Vahlne, J.E. (2009). The Uppsala internationalization process model revised: From liability of foreignness to liability of outsidership. Journal of International Business Studies, 40(9), 1411-1431. 
Johnson, D. (2012). "Why Kodak failed - and how to avoid the same fate"; $C B S$ MoneyWatch available at http://www.cbsnews.com/8301-505143_16257363629/why-kodak-failed-and-how-to-avoid-the-same-fate/ [January 23，2012, 7:21 AM].

Kafouros, M.I. (2006). The Impact of the Internet on R\&D-Efficiency: Theory and Evidence. Technovation, 26(7), 827-835.

Kafouros, M.I, Buckley, P.J., Sharp, J., \& Wang, C.Q. (2008). The role of internationalization in explaining innovation performance. Technovation, 28(1-2), 6374.

Kafouros, M.I., Buckley, P.J., \& Clegg, J. (2012). The effects of global knowledge reservoirs on the productivity of multinational enterprises: The role of international depth and breadth. Research Policy, 41(5), 848-861.

Kafouros, M., Hashai, N., \& Wang, C. (2011). Building Effective R\&D Portfolios: Location Choices and Performance Consequences. Paper presented at the $37^{\text {th }}$ annual conference of the EIBA, December,Bucharest: http://www.bursedoctorale.ro/public/documente/conferinte/1332193503 Content.pdf

Karim, S., \& Mitchell, W. (2000). Path dependent and path-breaking change: reconfiguring business resources following acquisitions in the U.S. medical sector, 1978-1995. Strategic Management Journal, 21(10), 1061-1081.

Katila, R., \& Ahuja, G. (2002). Something old, something new: a longitudinal study of search behavior and new product innovation. Academy of Management Journal, 45(6), 11831194.

Knight, G.A., \& Cavusgil, T. (2004). Innovation, organizational capabilities, and the bornglobal firm. Journal of International Business Studies, 35(2), 124-141.

Kobrin, S.J. (1991). An Empirical Analysis of the Determinants of Global Integration. Strategic Management Journal, 12, 17-31.

Kogut, B., Zander, U. (1992). Knowledge of the firm, combinative capabilities, and the replication of technology. Organization Science, 3(3), 383-396.

Kogut, B., Zander, U. (1993). Knowledge of the firm and the evolutionary theory of the multinational corporation. Journal of International Business Studies, 24(4), 625-645.

Kotabe, M. (1990). The Relationship between Offshore Sourcing and Innovativeness of US Multinational Firms: An Empirical Investigation. Journal of International Business Studies, 21(4), 623-638.

Kotabe, M., Dunlap-Hinkler, D., Parente, R., \& Mishra, H.A. (2007). Determinants of crossnational knowledge transfer and its effect on firm innovation. Journal of International Business Studies, 38, 259-282. 
Kotabe, M., Srinivasan, S.S., \& Aulakh, P.S. (2002). Multinationality and firm performance: The moderating role of R\&D and marketing capabilities. Journal of International Business Studies, 33(1), 79-97.

Langlois, R.N. (1992). Transaction Cost Economics in Real Time. Industrial and Corporate Change, 1(1), 99-127.

Lane, P.J., \& Lubatkin, M. (1998). Relative absorptive capacity and interorganizational learning. Strategic Management Journal, 19(5), 461-477.

Leiponen, A., \& Helfat, C. E. (2010). Innovation objectives, knowledge sources, and the benefits of breadth. Strategic Management Journal, 31(2), 224-236.

Leonard-Barton, D. (1992). Core capabilities and core rigidities: A paradox in managing new product development. Strategic Management Journal, 13(S1), 111-125.

Levitt, B., \& March, J.G. (1988). Organizational learning. Annual Review of Sociology, 14: 319-340.

Luo, Y. (2002). Capability exploitation and building in a foreign market: implications for multinational enterprises. Organization Science, 13(1), 48-63.

March, J.G. (1991). Exploration and exploitation in organizational learning. Organization Science, 2(1), 71-87.

Meyer, K. E., Mudambi, R., \& Narula, R. (2011). Multinational enterprises and local contexts: the opportunities and challenges of multiple embeddedness. Journal of Management Studies, 48(2), 235-252.

Meyer, K.E., Wright, M., \& Pruthi, S. (2009). Managing knowledge in foreign entries strategies: a resource based view analysis. Strategic Management Journal, 30(5), 557574

Miller, K.D. (2002). Knowledge inventories and managerial myopia. Strategic Management Journal, 23(8), 689-706.

Miller, T.L.(2008). Internationalization, search, and change: an organizational learning model of strategic change in the pharmaceutical industry. Thesis dissertation, available at http://repository.tamu.edu/bitstream/handle/1969.1/ETD-TAMU-3015/MILLERDISSERTATION.pdf?sequence $=1$

Mudambi, R., \& Zahra, S.A. (2007). The survival of international new ventures. Journal of International Business Studies, 38(2), 333-352.

Oviatt, B.M., \& McDougall, P.P. (1994). Toward a theory of international new ventures. Journal of International Business Studies, 25(1), 45-64.

Oviatt, B.M., \& McDougall, P.P. (2005). Defining international Entrepreneurship and Modeling the Speed of Internationalization. Entrepreneurship Theory and Practice, 29(5), 537-553. 
O'Reilly III, C.A., \& Tushman, M. (2008). Ambidexterity as a Dynamic Capability: Resolving the Innovator's Dilemma. Research in Organizational Behavior, 28, 185206.

Pedersen, T., \& Shaver, M.J. (2011). Internationalization revisited: the big step hypothesis. Global Strategy Journal, 1(3-4), 263-274.

Penrose E. (1959). The Theory of the Growth of the Firm. Basil Blackwell, London.

Pepitone, J. (2013). Cisco's reinvention is paying off. CNN Money available at http://money.cnn.com/2013/02/13/technology/enterprise/cisco-earnings/

Pitelis, C., Teece, D. (2010). Cross-border market co-creation, dynamic capabilities and the entrepreneurial theory of the multinational enterprise. Oxford University Press, 19(4), 1247-1270.

Rosenkoph, L., \& Almeida, P. (2003). Overcoming local search through alliances and mobility. Management Science, 49: 751-766.

Rugman, A, \& Oh, C.H. (2012). Why the Home Region Matters: Location and Regional Multinationals, British Journal of Management (in press).

Sapienza, H.J., Autio, E., George, G., \& Zahra, S.A. (2006). A Capabilities Perspective on the Effects of Early Internationalization on Firm Survival and Growth. The Academy of Management Review, 31(4), 914-933.

Sanna-Randaccio, F., \& Veugelers, R. (2007). Multinational Knowledge Spillovers with Decentralised R\&D: A Game-Theoretic Approach. Journal of International Business Studies, 38(1), 47-63.

Santos, J., Doz, Y., \& Williamson, P. (2004). Is your innovation process global? MIT Sloan Management Review, 45(4), 31-37.

Schilke, O. (2014). On the contingent value of dynamic capabilities for competitive advantage: the nonlinear moderating effect of environmental dynamism. Strategic Management Journal, 35, 179-203

Schleimer, C.S., \& Pedersen, T. (2014). The effect of MNC parent effort and social structure on subsidiary absorbtive capacity. Journal of International Business Studies, 45(3), 303-320.

Schueffel, P., Amann, W., \& Herbolzheimer† E. (2011). Internationalization of new ventures: tests of growth and survival. Multinational Business Review, 19(4), 376-403.

Slangen, A.H.L, \& Hennart, J-F. (2007). Greenfield or acquisition entry: A review of the empirical foreign establishment mode literature. Journal of International Management, 13(4), 403-429. 
Song, J., Shin, J. (2008). The paradox of technological capabilities: a study of knowledge sourcing from host countries of overseas R\&D operations. Journal of International Business studies, 39, 291-303.

Stopford, J.M, \& Baden-Fuller, C.W. (1994). Creating corporate entrepreneurship. Strategic Management Journal, 15 (7), 521-536.

Suder, G. (2013). Regional Trade Agreements and Regionalisation: Motivations and limits of a global phenomenon. Australian National University Center for European Studies Brifing Paper Series 4.1. Available at: http://ces.anu.edu.au/.

Teece, D.J. (2007). Explicating dynamic capabilities: The nature and microfoundations of (sustainable) enterprise performance. Strategic Management Journal, 28(13), 13191350.

Teece, D.J. (2012). Dynamic capabilities: routines versus entrepreneurial action. Journal of Management Studies, 49(8), 1395-1401.

Teece, D.J. (2014). A dynamic capabilities-based entrepreneurial theory of the multinational enterprise. Journal of International Business Studies, 45, 8-37.

Teece, D.J, Pisano, G., \& Shuen, A. (1997). Dynamic Capabilities and Strategic Management. Strategic Management Journal, 18(7), 509-533.

Thurm, S. (2003). After the Boom, Cisco is learning to go slow. Wall Street Journal. Article available at: http://online.wsj.com/articles/SB105225572953328200

Vahlne, J.E, \& Johanson J. (2013). The Uppsala model on evolution of the multinational business enterprise- from internationalization to coordination of networks. International Marketing Review, 30 (3), 189-201.

Vermeulen F. (2005). How acquisitions can revitalize companies. MIT Sloan Management Review, 48(4), 45-51.

Williamson, O.E. (1981). The economics of organization: The transaction cost approach. American journal of sociology, 87(3), 548-577.

Winter SG. (1991). On Coase, Competence, and the Corporation in The Nature of the Firm: Origins, Evolution, and Development Oliver E. Williamson and Sidney G. Winter (eds), Oxford: Basil Blackwell.

Woodward, D.P, \& Rolfe, R.J. (1993). The Location of Export-Oriented Foreign Direct Investment in the Caribbean Basin. Journal of International Business Studies, 24(1), 121-144.

Zahra, S.A. (2005). A theory of international new ventures: A decade of research. Journal of International Business Studies, 36(1), 20-28.

Zahra, S.A, \& George, G. (2002). Absorptive capacity: a review, reconceptualization and extension. Academy of Management Review, 27(2), 185-203. 
Zahra, S.A, Ireland, D.R., \& Hitt, M.A. (2000). International Expansion by New Venture Firms: International Diversity, Mode of Market Entry, Technological Learning, and Performance. The Academy of Management Journal, 43(5), 925-950.

Zhao, H., Lou, Y., \& Suh T. (2004). Transaction cost determinants and ownership-based entry mode choice: a meta-analysis review. Journal of International Business Studies, $35(6), 524-544$.

Zhou, C., Delios, A., \& YuYang, J. (2002). Locational determinants of Japanese foreign direct investment in China. Asia Pacific of Management, 19(1), 63-86.

Zeschky, M., Widenmayer, B., \& Gassmann, O. (2014). Organising for reverse innovation in Western MNCs: the role of frugal product innovation capabilities, International Journal of Technology Management, 64 (2-4), 255-268. 